\title{
Informal nature experience on the school playground
}

DOI 10.1515/ijtr-2015-0004

received March 20, 2015; accepted June 15, 2015

Abstract: In Germany, all-day care and all-day schooling are currently increasing on a large-scale. The extended time children spend in educational institutions could potentially result in limited access to nature experience for children. On the other hand, it could equally create opportunities for informal nature experience if school playgrounds have a specific nature-oriented design. This article is written from the perspective of a primary school teacher and presents the findings of a meta-analysis which looks at the impact nature experience has on the development of children. Furthermore, the first results of a research study on green playgrounds in primary schools is discussed. The results so far seem to indicate that green school playgrounds have the potential of providing nature experience particularly for primary students.

Keywords: child development, nature, schoolground, elementary school, informal learning

\section{Introduction}

Elementary school teachers have various responsibilities transmitted in a wide variety of contexts. Some areas of responsibility are explicitly named, others are generally expected, and sometimes the individual teacher assumes responsibilities. One such responsibility, which usually emerges during the process of a professional career, is to protect the children from those who mean well. This seems to be a paradox. And it is one indeed. But the fact

\footnotetext{
*Corresponding author: Andreas Raith, University of Education Ludwigsburg, Reuteallee 46, 71634 Ludwigsburg, Germany, raith@ ph-ludwigsburg, Tel: +49 7141 140-337
}

is that elementary school children are the focus of almost all interest groups. If you want to change things, you need to start with those in their early years and the word has spread. Consequently all who are aiming at developing society or just at promoting an idea want access to the youngest children. In Germany such issues of interest currently are, sexual orientation, equality, environmentalism, a healthy diet and many more. Most of these ambitions are reasonable and only few have a non-serious or solely commercial background. However, schools are overwhelmed by inquiries and projects on a daily basis. At the end of the day, after political and administrative decisions have been made, a primary teacher usually needs to decide as part of the school staff which projects and ideas to allow access to the classroom and which to deny access. Because of the sheer amount of opportunities however, it is impossible for a teacher to approve everything.

Until recently this was part of my daily routine. I was a teacher at a primary school in South Germany and am still teaching at this school once a week. At this school, social programs, programs to support students' self-awareness, healthy diet programs, and sports exercise programs are offered. What is lacking, however, is an environmental education program. The reason for this is the high number of already established programs and the considerable distance to the next forest. When teaching the topic 'Forest' I frequently went to the wood with my class because I love nature myself. Nevertheless, I always considered programs for social learning of higher value than the contact with nature. That is why I did not conduct any ongoing nature education programs and mostly rejected enquiries of environmental educators for my classes.

Nearly two years ago I accepted a postgraduate research position at the Ludwigsburg University of Education in the field of informal learning processes on near-natural school playgrounds. In cooperation with professor Armin Lude, I conducted a meta-analysis on the impact of nature experience on child development and started with first open observations on school playgrounds (The meta-analysis was commissioned by the “Stiftung Forum Bildung Natur")(Raith \& Lude 2014). The results of this meta-analysis considerably changed my 
view on what has real significance for children and also opened up new perspectives for everyday school life.

\section{Meta-analysis on the influence of nature on child development}

The research questions of the meta-analysis were as follows: Which studies are concerned with the impact of nature on child development? Which specific areas of child development were researched? Which were the findings on the impact of nature? To find this out, 115 studies were researched, which met the predetermined criteria, drawn from databases, collections of literature, and in references of already identified publications.

The research studies ranged from evaluations of forest kindergartens and environmental education programs to full-scale quantitative studies. The research interests in child development proved to be manifold. Accordingly, the research approaches of the studies varied significantly. Many of the published studies are not comparable because of their different context, purpose and research design. Nonetheless we were able to summarise a considerable number of results.

\subsection{The influence of nature experiences on the mental development of children}

Several studies indicate that time spent in nature has a positive impact on specific aspects of a child's mental development. Most significant were the findings on the ability to concentrate. The studies were carried out with children who were affected by Attention Deficit Hyperactivity Disorder (ADHD) and with others who were not. Some of the studies comprised of interviews with parents and teachers and other studies involved experimental designs with standardised concentration tests. The results consistently proved that children had an increased ability to concentrate during or directly after a nature experience. (Grahn et al. 1997; Faber Taylor \& Kuo 2001; Häfner 2002; Kuo \& Faber Taylor 2004; O’Brien \& Murray 2005; Faber Taylor \& Kuo 2009; Griffiths 2010; van den Berg \& van den Berg 2011).

Creativity tests with children from forest kindergartens and with children from regular kindergartens also showed that children who had spent a day in nature achieved better results. However, this effect only showed with children who spent every day of the week in the forest as opposed to those who were only one day a week in the forest (Kiener 2003; Lettieri 2004). Interviews with parents and teachers further confirmed the correlation between nature experience and creativity, at least concerning the perception of the respondents (Kiener \& Stucki 2001; Häfner 2002; Dyment 2005; Waite \& Rea 2006).

Several studies showed another positive influence of nature experience, namely on the self-esteem of children (Palmberg \& Kuru 2000, Kiener \& Stucki 2001; Murray 2003; O’Brien \& Murray 2003; O'Brien \& Murray 2005; O’Brien \& Murray 2006; Berger 2008; Griffiths et al. 2010). A survey by Wells and Evans determined the wellbeing of children in stressful situations with the help of psychological rating scales in correlation to their living environment, showed that nature experience can help children to lower mental stress. The buffering effect proved to be strongest with children who had the highest mental stress rates. (Wells \& Evans 2003). Quantitative and qualitative studies in general indicated an improved wellbeing of children while engaging with nature (Martin 2003; von den Berg \& van den Berg 2011). In a pre-post-test survey by Han, this improved wellbeing was already triggered just through greenery in the classroom (Han 2009).

\subsection{The influence of nature experience on the social development of children}

There is evidence suggesting that the social behavior of children improves in nature. This is based on the observation of children in different environments and on interviews with parents and teachers (van den Berg \& van den Berg 2011; Dyment 2005; Dyment \& Bell 2005a; Dyment \& Bell 2005b). According to parents and teachers, the improved social behavior, after the children have spent time in nature, is maintained for a considerably longer period of time (Dyment 2005; Kiener \& Stucki 2001). Another study showed that elementary school teachers classified children who visited a forest kindergarten before elementary school as socially more competent, during their first year of elementary school, in comparison to children who visited a regular kindergarten (Häfner 2002).

Playing habits of children in natural environments is a field that has been researched quite extensively compared to other fields in question. It is evident that children's playing becomes more diverse, intense, and creative in natural environments. Children include the environment into their games. It can be said that the more diverse the environment is the more likely it is that the games that children play will vary as well. Regarding this variety, even the weather and the season constitute important factors 
(Fiørtoft \& Sageie 2000; Beach 2003; Fiørtoft 2004). When asked about their games, children on nature experience playgrounds talked excitedly about their experiences and about observations they made. They reported about diverse role-plays whereas children on regular playgrounds only gave brief responses such as "we were on the swing and on the slide" (Berglez 2005). This means that the complexity of playing increases in green environments. The children play complex games, such as roleplays, more frequently whereas games on regular playgrounds are primarily based on monotonous repetitions (Grahn et al 1997; Schemel et al. 2005; Berglez 2005).

Similar results could be found in observations and surveys of children in forests, forest kindergartens, children in rural environments, and also children in urban settings with access to a forest area (Grahn et al. 1997; Fiørtoft \& Sageie 2000; Beach 2003; Dyment 2005; O’Brien 2005).

The time children spend playing in nature playgrounds is significantly longer than those of their peers in conventional playgrounds and the children spend less time sitting or standing and talking (Luchs \& Fikus 2012). Furthermore, the quantity of the children's playing increases in correlation with the quantity of vegetation. This was the result of observations on 64 public places in Chicago (Faber Taylor et al. 1998)

\subsection{The influence of nature experience on the physical development of children}

There is empirical evidence that nature experiences have benefits on the health of children. However besides the lack of quantitative studies, which could prove the significance of these correlations, there are even contradictory findings. A study conducted in Sweden showed that children who went to a forest kindergarten tended to get sick less often than children who went to a regular kindergarten (Grahn et al. 1997). A study researching 10 forest kindergartens and 4 regular kindergartens in Germany however did not yield the same results. There was no difference between the children from the forest kindergartens and the children from the regular kindergartens concerning the children's health (Scholz \& Krombholz 2007). The findings of a study in Taiwan differed yet again: in a classroom full of greenery, classes had less cases of illness than classes, which didn't have plants in their classroom (Han 2009). Several surveys of parents and teachers proved this correlation between a child's health and the time spent in nature (Kiener \& Stucki 2001; Dyment 2005). A large-scale quantitative study based in the US showed a significant correlation between the number of trees in a residential area and the number of pediatric asthma attacks. Although sociographical data and traffic density was considered, the authors could not prove a direct correlation between the trees and asthmatic illnesses (Lovasi et al. 2008).

The current state of research concerning children's motion in nature is much more precise. Children's motions in nature are significantly more active and more frequent than those of children indoors. A study in England showed that the motion intensity was even five times as high in nature. However, there was no significant difference between a nature-like environment and a non-nature-like environment in the outdoors. (Wheeler et al. 2010). The fact that it happens outdoors seems to be most significant for children's motion. Other studies on playgrounds and schoolyards confirmed the same results (Fiørtoft et al. 2009; Haug et al. 2010; Storli 2010). What all these studies have in common is the measuring of motion intensity, but not its quality. According to Fiørtoft and colleagues, children's motion patterns when playing in forest areas could indeed be more diverse than those of children playing on asphalt surface areas (Fiørtoft et al. 2009).

Several studies of children in forest kindergartens evidenced them having better gross motor skills development than their peers in regular kindergartens (Grahn et al. 1997; Kiener 2003; Lettieri 2004; Scholz \& Krombolz 2007). But this could very well be limited to the gross motor skills as such because the children's fine motor skills were only partly or not at all developed beyond those of their peers. (Lettieri 2004; Kiener 2003).

Two large-scale quantitative studies in the US researched the correlation between children's and teenager's body-mass-index and recreational attractions and parks, respectively greenery, in residential areas. Bell and colleagues found that increasing greenery in a residential area correlated with a lower BMI of the children living there (Bell et al. 2008). Nonetheless, it needs to be considered that the correlation could have its cause in demographic factors. According to a study by Wolch et al., open access to parks significantly reduces the risk of obesity. The impact of open access to leisure time activities, such as sports clubs, was however even ten times higher than the impact of accessible parks (Wolch et al. 2011).

\subsection{The influence of nature experiences on children's attitudes towards nature}

Several studies show that concepts about what nature is and what nature means to the individual evolve from 
ones own physical experience of nature. (Palmberg \& Kuru 2000; Meske 2011; Aquirre-Bielschowsky 2012). Bixler and colleagues proved that teenagers who used to play more frequently in nature as children were more interested in near-natural activities and were less interested in typical socially oriented youth activities (Bixler et al. 2002). However these concepts don't seem to be directly related to nature experiences as such. The concepts are rather transmitted through a temporary entity: the cultural and social reference systems of the individual child. A comparison between Japanese and German children concerning their concepts of nature showed that the concepts were strongly influenced by the respective culture. Particular aspects did only occur in one of the two groups at a time and the Japanese children could develop more consistent concepts of nature than the German children, by integrating spiritual components. (Gebauer \& Harada 2005; Gebauer 2007). Several international studies confirm the relevance of collective nature experiences with friends and family for developing images of nature (Meske 2011). Furthermore, the studies also confirm the significant impact of family values on the children's closeness to nature. In fact, the family values proved to be the strongest predictor for closeness to nature, followed by nature experiences (Cheng \& Monroe 2012).

There are further results concerning children's attitudes towards nature conservation and environmental action. In 2005, within the scope of the "LBSKinderbarometer" (an initiative with the goal to hear children's opinions on important matters) in North RhineWestphalia, the relationship of children with nature was examined. The results showed a weak but significant correlation between the frequency of staying in nature and the importance of nature conservation for the respondents (Hallmann et al. 2005).

The studies by Bögeholz and Lude show that nature experience has an effect on environmental action. Bögeholz and Lude distinguished nature experiences into different nature experience dimensions and they demonstrated that specific aspects of experience had a stronger impact on the environmental action than others. These aspects of nature experiences are the aesthetic perception of nature, the discovery exploration of nature, and nature experiences connected to aspects of nature conservation (Bögeholz 1999; Lude 2001).

\section{Implications of the meta-analysis}

Many of the results need further investigation and need to be evaluated in terms of their significance. The findings in most of the fields are not enough to make generalised statements. There is however a wide variety of findings that suggest contact with nature as a likely significant factor in child development. Nature experience seems to at least provide potential development, which gets lost if contact to nature is lacking.

I was personally affected by this result as my school does not put a high emphasis on nature experience. Nature is an integral part of the given curriculum, but most teachers only cover it within the classroom. Until this meta-analysis was undertaken I wasn't aware of the fact that this could cause a loss of development potential to the children

The situation in Germany is being further aggravated because the German school system is momentarily facing a transition phase. Traditionally, German students attend half-day schools and spend most of their afternoons at home. They need to do their school homework, but at least theoretically they have enough time to spend in nature. Primarily for demographic and economic reasons, this school system is being transitioned into an all-day school system. Birth rates in Germany are in decline. It is therefore hoped that all-day childcare would create better opportunities for parents to reconcile family and working life, and thus birth rates could be raised. Beyond raising birth rates, it should give both parents the opportunity to participate in the labor market. At present parents can decide for themselves, which school-type their children should attend. However, it can be expected that sooner or later all children in Germany will attend all-day schools as is common policy in many other countries. This would result in even less opportunity for children to spend time in nature during the week. On the other hand, new opportunities for nature experience could emerge, if school premises were redesigned naturally. It could be possible for children to have daily informal nature experiences, which were not pedagogically motivated in the first place.

\section{Observations on a school playground}

In order to assess the potential of near-natural school playgrounds, I started a multistage research project. The main research questions are as follows: For which purpose 
and to what extent do children use green school playgrounds? Which kinds of nature experiences take place and to which extent do they take place? How do nature experiences on the school playground influence attitudes towards nature?

In the first phase of the research project, behavioral patterns of children on green school playgrounds will be determined by means of observation and categories and hypotheses will be formed. In a second phase, the hypotheses of phase one will be tested quantitatively by means of observations and interviews. In phase three a test will be used that is currently being developed by Schaal et al. (2015) to determine the influence of near-naturally designed school playgrounds on children's attitudes towards nature. The study is currently in the second phase of the research process.

For the first research phase, a school was chosen that can offer a wide variety of school playground structures and has also different class levels. This school is situated in the Stuttgart area in southern Germany. The school has 526 students from grade one to grade ten and the school premises are diversely structured. Some areas have been naturally redesigned, including various kinds of play equipment, a paved courtyard, and a sports field with artificial grass. Eight observation positions were defined from which are the entire school ground could be overviewed. From each position an observation was carried out during a school break and the observations were recorded and then transcribed afterwards. All of the observed patterns of behavior were categorised in several cycles.

Some remarkable tendencies have been revealed. Two dimensions of contact with nature could be determined: a behavioral dimension and an environmental dimension. In the behavioral dimension, the connection to nature is being expressed through the object of behavioral action. This could more or less involve contact with nature. Children could for instance either play with leaves or with a ball. The object of behavioral action can have a reference to nature, independently of its environment. For example, the children could play with leaves on an asphalt surface. The environment of behavioral action on the other hand, can have a reference to nature independently of the object of behavioral action. The children can play with a ball on an asphalt surface or on grass.

Of all observed actions, which were related to an element of nature as its object of behavioral action (e.g. playing with a branch or collecting leaves), $93 \%$ of these actions account for elementary students (grades 1 to 4 ) and only $7 \%$ account for secondary students (grades 5 to 10). Concerning the distribution among the primary students, 69\% account for children from grade 1 and 2 and
$31 \%$ account for grade 3 and 4 . Also concerning the environment of behavioral action, primarily younger children frequented a natural environment.

This is the first evaluations of the available qualitative findings.. A quantitative testing will be carried out on a larger sample with several schools in the second phase of the research project. The research suggests that nature attractions on school playgrounds are more likely to be used specifically by primary students and even among these students it seems to be the younger students who use them.

\section{The observation outcome}

At first sight these temporary findings may seem to be drastic. The frequency of children engaging in nature experiences already decreases starting from grade 3 and in secondary school the interest of teenagers even seems to disappear. But on the other hand the findings also show that younger children make use of nature attractions either as play environments or as playing content. This seems to happen entirely without pedagogic interference or an organised nature experience program. If school playgrounds at primary schools were consequently naturally designed, children would have nature experiences on a daily basis without schools or individual teachers having to start another program to be run on the expense of teaching time. If all primary schools had such a school playground design as standard, children would have a joint contingent of nature experience, precisely during the period of time they are receptive to this opportunity.

To date the significance of these findings has not been tested, and will be carried out from September 2015. Should the assumptions prove to be true the children's experiences will be examined by conducting interviews. Finally, tests will be carried out to find out whether nature experiences on the school playground are sufficient to have an impact on children's attitudes towards nature.

\section{My reflections}

For me as a primary school teacher, this is a groundbreaking perspective. We could possibly be in a position to make development potential available to primary students by providing nature experiences, which are proven to be significant, without another burdening pedagogical program. 
Frankly speaking, I was rather surprised by the outcome of our research. I expected scientific results, which might be interesting or would be recognised in specific educational discourses. But that my personal perspective on elementary school would be changed and that this would spark a new vision for a realistic and feasible implementation in school has been a new experience. I realised that providing nature experiences for children by creating green school grounds could be more than just offering one out of many programs, which at the end would only be used by a few schools with motivated teachers. I learned that every elementary school could potentially provide that option without changing the school program but by changing the setting of the schoolground.

Since the meta-analysis has been published, I received invitations from various organisations, even parent and teacher societies, to present the research. It is possible that I not only found nice results but a vision. If so, my target audience is not only the scientific community, but the wider community as well.

The school where I am teaching is currently being transitioned into an all-day school. To this end construction measures are underway which could include redesigning the school playground. The school staff who are aware of the results of my study, are already discussing a green design, and have filed an application to the school administration for our school playground to be redesigned and for a green classroom nearby the school.

Funding source: Stiftung Forum Bildung Natur, Berlin, Germany

\section{Reference list}

[1] Aguirre-Bielschowsky, I., Freeman, C., \& Vass, E. (2012): Influences on children's environmental cognition: A comparative analysis of New Zealand and Mexico. Environmental Education Research, 18(1), 91-115

[2] Beach, B. A. (2003): Rural children's play in the natural environment. In D. E. Lytle (Hrsg.), Play and educational theory and practice. Westport, CT US: Praeger Publishers/Greenwood Publishing Group, 183-194

[3] Bell, J. F., Wilson, J. S., \& Liu, G. C. (2008): Neighborhood greenness and 2-year changes in body mass index of children and youth. American Journal of Preventive Medicine, 35(6), 547-553

[4] Berger, R. (2008): Going on a journey: a case study of nature therapy with children with a learning difficulty. Emotional and Behavioural Difficulties, 13(4), 315-326

[5] Berglez, R. (2005): Beobachtungen und qualitative Befragungen in Naturerfahrungsräumen und konventionellen
Spielplätzen. In Naturerfahrungsräume im besiedelten Bereich. Nürtingen: Hochschulbund Nürtingen/Geislingen e.V., 50-89

[6] Bixler, R. D., Floyd, M. F., \& Hammitt, W. E. (2002):

Environmental socialization: Quantitative tests of the childhood play hypothesis. Environment and Behavior, 34(6), 795-818

[7] Bögeholz, S. (1999): Qualitäten primärer Naturerfahrung und ihr Zusammenhang mit Umweltwissen und Umwelthandeln. Opladen: Leske + Budrich

[8] Cheng, J. C.-H. \& Monroe, M. C. (2012): Connection to nature: Children's affective attitude toward nature. Environment and Behavior, 44(1), 31-49

[9] Dyment, J. E. (2005): Gaining Ground: The Power and Potential of School Ground Greening in the Toronto District School Board. http://www.evergreen.ca/en/resources/school-groundgreening/research-and-policy/ (accessed 10th December 2013)

[10] Dyment, J. E., \& Bell, A. C. (2008a): "Our garden is colour blind, inclusive and warm": reflections on green school grounds and social inclusion. International Journal of Inclusive Education, 12(2), 169-183

[11] Dyment, J. E., \& Bell, A. C. (2008b): Grounds for movement: Green school grounds as sites for promoting physical activity. Health Education Research, 23(6), 952-962

[12] Dyment, J. E., Bell, A. C., \& Lucas, A. J. (2009): The relationship between school ground design and intensity of physical activity. Children's Geographies, 7(3), 261-276

[13] Faber Taylor, A., Wiley, A., Kuo, F. E., \& Sullivan, W. C. (1998): Growing up in the Inner City - Green Spaces as Places to Grow. Environment and Behaviour, 30(1), 3-27

[14] Faber Taylor, A., \& Kuo, F. E. (2009): Children With Attention Deficits Concentrate Better After Walk in the Park. Journal of Attention Disorders, 12(5), 402-409

[15] Faber Taylor, A., \& Kuo, F. E. (Ming). (2011): Could Exposure to Everyday Green Spaces Help Treat ADHD? Evidence from Children's Play Settings. Applied Psychology: Health and Well-Being, 3(3), 281-303

[16] Fjørtoft, I., \& Sageie, J. (2000): The natural environment as a playground for children Landscape description and analyses of a natural playscape. Landscape and Urban Planning, 48, 83-97

[17] Fjørtoft, I. (2004): Landscape as Playscape: The Effects of Natural Environments on Children's Play and Motor Development. Children, Youth and Environments, 14(2), 21-44

[18] Fjørtoft, I., Kristoffersen, B., \& Sageie, J. (2009): Children in schoolyards: Tracking movement patterns and physical activity in schoolyards using global positioning system and heart rate monitoring. Landscape and Urban Planning, 93, 210-217

[19] Gebauer, M. (2007): Kind und Naturerfahrung: naturbezogene Konzeptbildung im Kindesalter. Hamburg: Verlag Dr. Kovač

[20] Gebauer, M., \& Harada, N. (2005): Wie Kinder die Natur erleben- Ergebnisse einer kulturvergleichenden Studie in Japan und Deutschland. In U. Unterbruner \& Forum Umweltbildung (Eds.), Natur erleben. Innsbruck, Wien, Bozen: Studien Verlag, 45-61

[21] Grahn, P., Mårtensson, F., Lindblad, B., Nilsson, P., \& Ekman, A. (1997): Ute på Dagis Stad and Land. http://www.friluftsframjandet.se/c/document_library/get_file?folderld=4413355 \&name $=$ DLFE-61101.pdf (accessed 18th Oktober 2013)

[22] Griffiths, E., Elniff-Larsen, A., \& Jones, L. (2010): Evaluation of the Ysgol Llanfair Forest School. http://www.forestry.gov.uk/ forestry/INFD-8PKKXQ (accessed 19th Oktober 2013) 
[23] Häfner, P. (2002): Natur- und Waldkindergärten in Deutschland - eine Alternative zum Regelkindergarten in der vorschulischen Erziehung. http://www.ub.uni-heidelberg.de/archiv/3135 (accessed 19th Oktober 2013)

[24] Hallmann, S., Klöckner, C. A., Beisenkamp, A., \& Kuhlmann, U. (2005): Freiheit, Ästhetik oder Bedrohung? Wie Kinder Natur bewerten. Umweltpsychologie, 9(2), 88-108

[25] Han, K.-T. (2009): Influence of Limitedly visible Leafy Indoor Plants on the Psychology, Behavior, and Health of Students at a Junior High School in Taiwan. Environment and Behavior, 41(5), 658-692

[26] Harvey, M. R. (1989): The Relationship between Children's Experiences with Vegetation on School Grounds and Their Environmental Attitudes. Journal of Environmental Education, 21(2), 9-15

[27] Haug, E., Torsheim, T., Sallis, J. F., \& Samdal, O. (2010): The characteristics of the outdoor school environment associated with physical activity. Health Education Research, 25(2), 248-256

[28] Kiener, S. (2003): Kindergärten in der Natur - Kindergärten in die Natur? Fördert das Spielen in der Natur die Entwicklung der Motorik und Kreativität von Kindergartenkindern? http://dusseverusse.ch/icc.asp?oid=8630 (accessed 15th Oktober 2013)

[29] Kiener, S., \& Stucki, S. (2001): Evaluation Naturspielgruppe Dusse Verusse - Zusammenfassung Elternbefragung. http:// dusse-verusse.ch/icc.asp?oid $=8630$ (accessed 19th Oktober 2013)

[30] Kuo, F. E., \& Faber Taylor, A. (2004): A Potential Natural Treatment for Attention-Deficit/Hyperactivity Disorder: Evidence From a National Study. American Jounal of Public Health, 94(9), 1580-1586

[31] Lettieri, R. (2004): Evaluationsbericht des ersten öffentlichen Waldkindergartens der Schweiz. In B. Gugerli-Dolder, M. Hüttenmoser, \& P. Lindemann-Matthies (Eds.), Was Kinder beweglich macht - Wahrnehmungs- und Bewegungsförderung im Kindergarten (pp. 76-81). Zürich: Verlag Pestalozzianum

[32] Louv, R. (2005): Last child in the woods: saving our children from nature-deficit disorder. Chapel Hill, NC: Algonquin Books of Chapel Hill

[33] Lovasi, G. S., Quinn, J. W., Neckerman, K. M., Perzanowski, M. S., \& Rundle, A. (2008): Children living in areas with more street trees have lower prevalence of asthma. Journal of Epidemiology \& Community Health, 62(7), 647-649

[34] Luchs, A., \& Fikus, M. (2012): Urbane Spiel- und Bewegungsräume - Untersuchung zum freien Spiel von Kindern im öffentlichen Raum. In Zukunfts-Handbuch Kindertageseinrichtungen - Begleit-CD Bildung und Soziales, Regensburg: Walhalla, 4118-4229

[35] Lude, A. (2001): Naturerfahrung und Naturschutzbewusstsein. Innsbruck: Studien Verlag

[36] Lueger, M. (2010): Interpretative Sozialforschung: Die Methoden. Wien: Facultas

[37] Martin, S. C. (2003): The Influence of Outdoor Schoolyard Experiences on Students' Environmental Knowledge, Attitudes, Behaviors, and Comfort Levels. Journal of Elementary Science Education, 15(2), 51-63

[38] Meske, M. (2011): “Natur ist für mich die Welt”. Lebensweltlich geprägte Naturbilder von Kindern. 1. Aufl. Wiesbaden: VS Verl. für Sozialwissenschaften
[39] Moore, R. C. (1986): The power of nature orientations of girls and boys toward biotic and abiotic play settings on a reconstructed schoolyard. Children's Environments Quarterly, 3(3), 52-69

[40] Murray, R. (2003): Forest School Evaluation Project - A Study in Wales. http://www.forestry.gov.uk/pdf/ForestSchoolWalesReport.pdf/\$FILE/ForestSchoolWalesReport.pdf (accessed 29th Oktober 2013)

[41] O'Brien, E. (2005): The impact of trees on the well-being of residents on two inner-London social housing estates. http:// www.forestry.gov.uk/ (accessed 29th Oktober 2013)

[42] O’Brien, L., \& Murray, R. (2005): “Such enthusiasm - a joy to see" An evaluation of Forest School in England. http://www. forestry.gov.uk/pdf/ForestSchool EnglandReport.pdf/\$FILE/ForestSchoolEnglandReport.pdf (accessed 26th Oktober 2013)

[43] O’Brien, L., \& Murray, R. (2006): A marvellous opportunity for children to learn: a participatory evaluation of forest school in England and Wales. Farnham, Surrey: Forest Research. http:// www.forestry.gov.uk/pdf/fr0112forestschoolsreport.pdf/\$FILE/ fr0112forestschoolsreport.pdf (accessed 26th Oktober 2013)

[44] Ozdemir, A., \& Yilmaz, O. (2008): Assessment of outdoor school environments and physical activity in Ankara's primary schools. Journal of Environmental Psychology, 28(3), 287-300

[45] Palmberg, I. E., \& Kuru, J. (2000): Outdoor activities as a basis for environmental responsibility. The Journal of Environmental Education, 31(4), 32-36

[46] Raith, A. \& Lude, A. (2014): Startkapital Natur - Wie Naturerfahrung die kindliche Entwicklung fördert. München: Oekom Verlag

[47] Roczen, N., Kaiser, F. G., Bogner, F. X. \& Wilson, M. (2014): A competence model for environmental education. Environment and Behaviour, 46(8), 972-992

[48] Schaal, S., Haas, A., Schaal, S. \& Lude, A. (2015): BioDiv2Go - theoretical model and scale development for location-based biodiversity GeoGames. Proposal ESERA 2015

[49] Schemel, H.-J., Reidl, K., \& Blinkert, B. (2005): Naturerfahrungsräume im besiedelten Bereich. Naturschutz Und Landschaftsplanung, 37(1), 5-15

[50] Scholz, U., \& Krombholz, H. (2007): Untersuchung zur körperlichen Leistungsfähigkeit von Kindern aus Waldkindergärten und Regelkindergärten. Motorik - Zeitschrift Für Motopädagogik Und Mototherapie, März 2007(1), 17-22

[51] Storli, R., \& Hagen, T. L. (2010): Affordances in outdoor environments and children's physically active play in pre-school. European Early Childhood Education Research Journal, 18(4), 445-456

[52] Van den Berg, A. E., \& van den Berg, C. G. (2011): A comparison of children with ADHD in a natural and built setting. Child: Care, Health and Development, 37(3), 430-439

[53] Waite, S., \& Rea, T. (2006): Pedagogy or place?: attributed contributions of outdoor learning to creative teaching and learning. http://www.leeds.ac.uk/educol/documents/162159. doc (accessed 25th Oktober 2013)

[54] Wells, N. M., \& Evans, G. W. (2003): Nearby Nature - A Buffer of Life Stress Among Rural Children. Environment and Behaviour, 35(3), 311-330

[55] Wheeler, B. W., Cooper, A. R., Page, A. S., \& Jago, R. (2010): Greenspace and children's physical activity: A GPS/GIS 
analysis of the PEACH project. Preventive Medicine, 51, 148-152

[56] Wolch, J., Jerrett, M., Reynolds, K., McConell, R., Chang, R., Dahmann, N., Berhane, K. (2011): Childhood obesity and proximity to urban parks and recreational resources: $A$ longitudinal cohort study. Health \& Place, 17, 207-214 